\title{
The impregnation of $\mathrm{ZnO}$ onto $\mathrm{ZSM}-5$ derived from red mud for photocatalytic degradation of methylene blue
}

\author{
Tehubijuluw Hellna, Riki Subagyo, Yuly Kusumawati* (D) and Didik Prasetyoko
}

\begin{abstract}
Photocatalytic degradation of Methylene Blue (MB) by zinc oxide/zeolite socony mobile-5 (ZnO/ZSM-5) composites was investigated. The ZSM-5 material was synthesized from red mud by a two-step hydrothermal method to which $\mathrm{ZnO}$ loadings at different mass ratios were subsequently performed. Characterizations using X-ray diffraction (XRD), Fourier transform infrared spectroscopy, and scanning electron microscopy were carried out to identify the formation of ZSM-5 and ZnO/ZSM-5. ZSM-5 and ZnO/ZSM-5 have cubic microcrystallite morphologies. ZnO loading in the ZnO/ZSM-5 composites was successfully performed and confirmed by the appearance of wurtzite peaks in the XRD spectra that matched the Joint Committee on Powder Diffraction Standards data. The presence of ZnO in ZSM-5 leading resulted in a decrease in the surface area and pore size as confirming by nitrogen adsorptiondesorption isotherm experiments. The band gap of the samples was measured using UV-Vis diffuse reflectance spectroscopy. The optimum photocatalytic degradation of MB was observed at a $\mathrm{ZnO}$ loading of $34 \% \mathrm{w} / \mathrm{w}$ dubbed $34-\mathrm{ZnO} / \mathrm{ZSM}-5$. The influence of the initial concentration of $\mathrm{MB}$ was also investigated at 80,90 , and $100 \mathrm{mg} \mathrm{L}^{-1}$ using 34-ZnO/ZSM-5 and ZSM-5. Liquid chromatography-mass spectrometry characterization was performed to analyze the degradation products.
\end{abstract}

Keywords: Red mud, ZSM-5, ZnO, Photocatalytic, Methylene blue

\section{Introduction}

Red mud (RM) is a sludge-like waste generated as a byproduct of bauxite processing. To produce one ton of aluminum from bauxite processing, 1.0 to 1.8 tons of high-alkalinity RM are generated, which amount to $35-40 \%$ of total bauxite ores [1]. Approximately 70 Mt of RM are generated worldwide annually; with the increasing demand for aluminum, this number also increases, and it was estimated to reach $4000 \mathrm{Mt}$ in 2015 [2].

With high alkalinity contents, the disposal of large amounts of RM has caused environmental problems, such as soil and groundwater contamination, and the formation of suspensions in water. In its dry form,

\footnotetext{
* Correspondence: y_kusumawati@chem.ts.ac.id

Department of Chemistry, Institut Teknologi Sepuluh Nopember, Surabaya 60111, Indonesia
}

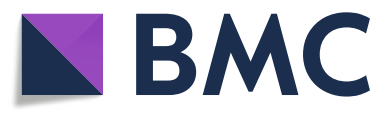

(อ The Author(s). 2021 Open Access This article is licensed under a Creative Commons Attribution 4.0 International License, which permits use, sharing, adaptation, distribution and reproduction in any medium or format, as long as you give

appropriate credit to the original author(s) and the source, provide a link to the Creative Commons licence, and indicate if changes were made. The images or other third party material in this article are included in the article's Creative Commons licence, unless indicated otherwise in a credit line to the material. If material is not included in the article's Creative Commons licence and your intended use is not permitted by statutory regulation or exceeds the permitted use, you will need to obtain permission directly from the copyright holder. To view a copy of this licence, visit http://creativecommons.org/licenses/by/4.0/. in its slurry form, its alkalinity is higher $(\mathrm{pH}>13)$ due to the presence of sodium hydroxide $(\mathrm{NaOH})$ and sodium bicarbonate $(1-6 \% \mathrm{w} / \mathrm{w})$ in the form of sodium oxide [4]. It has been reported that the accumulation of dry RM around bauxite processing plants causes dust pollution, leading to a serious health problem for the surrounding community [5]. To overcome the environmental problems caused by the accumulation of RM, especially in wastewater, various methods have been used for RM treatments, such as coagulation [6-8], adsorption [9, 10], hydrogenation $[11,12]$, dichlorination and hydrodechlorination [13, $14]$, and leaching $[15,16]$. In addition, $R M$ has been utilized for construction materials, catalysts, adsorbents, ceramics, and wastewater treatments $[17,18]$. 
One alternative to RM utilization is its use as an adsorbent. It accounts for $30 \%$ of RM utilizations, most of which are applied for wastewater treatments [18]. The adsorption technique for wastewater treatments is considered promising due to its flexibility and simple design, low cost and ease of operation, and higher efficiency compared to other techniques $[19,20]$, although the periodic replacement of pollutant-containing adsorbents remains a major drawback. As pollutants, e.g., dye compounds, accumulate in the adsorbents, further processing of the adsorbents is necessary, which is often expensive and less effective, thus causing other problems [21].

To overcome the problem of adsorbed pollutants in wastewater treatments, the use of semiconductors as photocatalysts for pollutant degradation, which has been widely used for pollutant removal [22], is a promising alternative, and the two most popular semiconductors for this purpose are zinc oxide $(\mathrm{ZnO})$ and titanium dioxide $\left(\mathrm{TiO}_{2}\right)$. In terms of particle preparation, $\mathrm{ZnO}$ has an upper hand over $\mathrm{TiO}_{2}$ since some $\mathrm{TiO}_{2}$ precursors require special handling due to their reactivity with air. $\mathrm{ZnO}$, on the other hand, is more stable, nontoxic, and inexpensive. In terms of band gap, both $\mathrm{ZnO}$ and $\mathrm{TiO}_{2}$ anatase have a close band gap, which corresponds to photocatalytic activity to decompose waste organic compounds [23]. In large amounts of dyes, however, the degradation process photocatalyzed by $\mathrm{ZnO}$ generates partial degradation products, which require further treatment or longer degradation times to decompose the dyes into carbon dioxide and water. Based on this issue, supporting materials to enhance its adsorption capability are needed.

As a supporting material for semiconductor photocatalysts, zeolite socony mobile-5 (ZSM-5) is a promising candidate due to its larger surface area and photocatalytic activity in addition to good mechanical and chemical stability. As reported by Shams-Ghahfarokhi and Nezamzadeh-Ejhieh [24], due to its sufficiently high hydrophobicity, ZSM-5 adsorbs more dye molecules on its surface, where hydroxyl radicals are generated in the photocatalytic processes, thus increasing the photocatalytic activity of the semiconductor. Additionally, ZSM-5 can be obtained from the conversion of RM owing to its high contents of alumina and silica, as reported in our previous study [25].

In this study, we prepared a $\mathrm{ZnO} / \mathrm{ZSM}-5$ composite for the photocatalyst using $\mathrm{ZnO}$ as the semiconductor photocatalyst and ZSM-5 from RM as the supporting material. $\mathrm{ZnO}$ was loaded on ZSM-5 at different ratios to optimize the $\mathrm{ZnO}$ loading. Their photocatalytic activities toward the decolorization of Methylene Blue (MB) as the dye compound at various concentrations were examined under ultraviolet-light emitting diode (UV-LED) irradiation.

\section{Materials and methods}

\subsection{Materials}

In this study, we used RM obtained from Bintan Island, Indonesia, $\mathrm{NaOH}$ 99\% (Merck), tetrapropylammonium hydroxide (TPAOH 40\% w/v solution in water, Merck), colloidal silica (Ludox 30\%, Aldrich), cetyltrimethylammonium bromide (CTAB, $\mathrm{C}_{19} \mathrm{H}_{42} \mathrm{BrN}$, Aldrich), zinc acetate dihydrate $\left(\mathrm{Zn}\left(\mathrm{CH}_{3} \mathrm{COO}\right)_{2} \cdot 2 \mathrm{H}_{2} \mathrm{O}\right.$, Merck), $\mathrm{MB}$ $\left(\mathrm{C}_{16} \mathrm{H}_{18} \mathrm{ClN}_{3} \mathrm{~S}\right.$, Merck), and distilled water.

\subsection{Preparation of ZSM-5}

ZSM-5 was synthesized from RM using the dualhydrothermal method [26] as follows. RM was pretreated by an alkaline fusion reaction at $450^{\circ} \mathrm{C}$ for $2 \mathrm{~h}$ before adding distilled water and stirring for $24 \mathrm{~h}$. The filtrate was separated and dried at $105^{\circ} \mathrm{C}$ for $24 \mathrm{~h}$. At molar compositions of 0.2 silicon dioxide $\left(\mathrm{SiO}_{2}\right): 0.004$ dialuminium trioxide: 0.04 tetrapropylammonium: 3.6 water, the resulting solid substance was used to prepare ZSM- 5 by dissolving it in distilled water. Ludox was then added to the solution under the stirring conditions for 8 h. A TPAOH solution that had been dissolved in distilled water was added to the solution and heated at $80^{\circ} \mathrm{C}$ for $6 \mathrm{~h}$. After completing the $6 \mathrm{~h}$ reaction, CTAB $\left(\mathrm{SiO}_{2} / \mathrm{CTAB}=3.85\right)$ was added to the solution, and it was stirred for $1 \mathrm{~h}$. The resulting gel was then heated in an autoclave at $150^{\circ} \mathrm{C}$ for $24 \mathrm{~h}$. The resulting white solid was filtered, washed with distilled water until neutral $\mathrm{pH}$, and then dried. The resulting white solid ZSM-5 was used for $\mathrm{ZnO}$ impregnation.

\subsection{Preparation of ZnO/ZSM-5}

The immobilization of $\mathrm{ZnO}$ in ZSM-5 was performed using a wet impregnation method [27] with some modifications. The details are as follows. Varying amounts of $\mathrm{Zn}\left(\mathrm{CH}_{3} \mathrm{COO}\right)_{2} \cdot 2 \mathrm{H}_{2} \mathrm{O}(20,34,54$, and $67 \% \mathrm{w} / \mathrm{w})$ and $0.3424 \mathrm{~g}$ of ZSM-5 were added to $10 \mathrm{~mL}$ of demineralized water. The mixture was then stirred using a hot plate magnetic stirrer for $3 \mathrm{~h}$ at $90^{\circ} \mathrm{C}$, dried at $110^{\circ} \mathrm{C}$ for $3 \mathrm{~h}$, and calcined for $6 \mathrm{~h}$ at $550^{\circ} \mathrm{C}\left(1 \mathrm{~h}\right.$ in a $\mathrm{N}_{2}$ environment and $6 \mathrm{~h}$ in open air). The resulting samples were denoted as $\mathrm{x}-\mathrm{ZnO} / \mathrm{ZSM}-5$ where $\mathrm{x}$ is the percentage of $\mathrm{ZnO}$ load.

\subsection{Characterization of ZSM-5 and ZnO/ZSM-5}

ZSM-5 and ZnO/ZSM-5 were characterized using X-ray diffraction (XRD), Fourier transform infrared spectroscopy (FTIR), Scanning electron microscopy (SEM), and Nitrogen $\left(\mathrm{N}_{2}\right)$ adsorption-desorption and UV-Vis diffuse reflectance spectroscopy (DRS). The crystallographic structures of the samples were identified using XRD (PANalytical X'pert Pro) with $\mathrm{Cu} K \alpha$ radiation in the range of $2 \theta=5-50^{\circ}$. The infrared spectra of the samples were recorded via FTIR (Shimadzu 8400S) using the 
kalium bromide disk technique. The morphologies of the samples were analyzed using SEM (JEOL 6360 LA). The diffuse reflectance spectra were analyzed using an Agilent Cary 60 UV-Vis/DRS. The Brunauer-EmmettTeller (BET) specific surface area and the BarrettJoyner-Halenda pore size distribution were analyzed using $\mathrm{N}_{2}$ adsorption-desorption isotherms in a Nova 1200 e Quantachrome instrument at $77 \mathrm{~K}$, where the samples were degassed under high vacuum for $2 \mathrm{~h}$ at $393 \mathrm{~K}$. All other sample characterizations were carried out at room temperature.

\subsection{Photocatalytic activity experiment}

The photocatalytic activities of ZnO/ZSM-5 and ZSM-5 were evaluated by performing photodegradation reactions in MB dye solution. The photocatalytic activity was analyzed in a reactor irradiated with a UV-LED strip (provided by EPILEDS with a $3 \mathrm{~W} \mathrm{~m}^{-1}$ power output and wavelength emission of $365 \mathrm{~nm}$ ) surrounding the external surface of the cylindrical body. The schematic design of the photocatalytic reactor is shown in Fig. 1.

Employing the Lambert-Beer law equation,

$$
A=\varepsilon b c
$$

where $\mathrm{A}$ is the absorbance, $\varepsilon$ is the absorption coefficient, $\mathrm{b}$ is the thickness of the solution, and $\mathrm{c}$ is the dye concentration in the solution at the sampling time. The absorbances depend linearly on the dye concentrations in the samples. The standard calibration curve was obtained by measuring the absorbances of the standard MB dye solutions using a UV-Vis spectrophotometer (Genesys 10S UV-Vis) at the MB maximum absorption wavelength of $664 \mathrm{~nm}$. All the measurements of dye concentration were performed within the range of the standard calibration curve, and thus the dilution factor was used to keep the absorbance within this range.

After the photodegradation experiments, the MB solution was analyzed using Thermo Scientific Liquid chromatography-mass spectrometry (LC-MS). The removal efficiency $(\mathrm{R})$ of the MB dye was calculated using Eq. (2),

$$
R=\frac{C_{0}-C}{C_{0}} \times 100 \%
$$

where $\mathrm{C}_{0}$ and $\mathrm{C}$ are the initial and final MB concentrations in the solution, respectively.

\section{Results and discussion}

\subsection{ZSM-5 formation from red mud}

The formation of synthesized ZSM-5 (SZSM-5) in this work was confirmed by the XRD and FTIR spectra as shown in Fig. 2. Figure 2a shows all the XRD peaks of the RM transformation. Initially, the XRD spectra indicated that the RM consisted of $\mathrm{SiO}_{2}$ polymorph (Inorganic Crystal Structure Database (ICSD), 170,482 at $\left.12.29 ; 18.30^{\circ}\right)$, gibbsite $\left(00-007-0324\right.$, at $\left.18.28 ; 20.31^{\circ}\right)$, boehmite $\left(00-021-1307\right.$, at $\left.38.38^{\circ}\right)$, hematite $(00-033$ 0664 , at $\left.33.15 ; 35.61^{\circ}\right)$, magnetite $(00-019-0629$, at $\left.35.42^{\circ}\right)$, goethite $\left(01-075-5065\right.$, at $\left.21.27 ; 36.72^{\circ}\right)$, quartz $\left(00-046-1045\right.$, at $\left.20.86 ; 26.64^{\circ}\right)$, and $\mathrm{TiO}_{2}$ anatase $(00$ 021-1272, at $25.28 ; 37.80^{\circ}$ ), where all of them matched the Joint Committee on Powder Diffraction Standards (JCPDS) and ICSD. These minerals were transformed into sodium silicate $\left(\mathrm{NaSiO}_{3}\right)$ and sodium aluminosilicate $\left(\mathrm{NaAlSiO}_{4}\right)$ by the alkali fusion reaction. The formation of $\mathrm{NaSiO}_{3}$ and $\mathrm{NaAlSiO}_{4}$ were confirmed from the XRD peaks at $2 \theta=17,19,23\left(\mathrm{NaSiO}_{3}\right)$, and $37^{\circ}$ $\left(\mathrm{NaAlSiO}_{4}\right)$ [28] at the pre-treatment red mud (PT-RM) diffraction peaks. PT-RM was transformed to ZSM-5 via a hydrothermal reaction for $6 \mathrm{~h}$. Compared to commercial ZSM-5 (CZSM-5), SZSM-5 was successfully synthesized in this study, as indicated by the appearance of mordenite framework inverted (MFI) peaks as the characteristic peak of ZSM-5 [29].

To investigate the functional group of SZSM-5, FTIR spectra were recorded as shown in Fig. 2b. The spectra

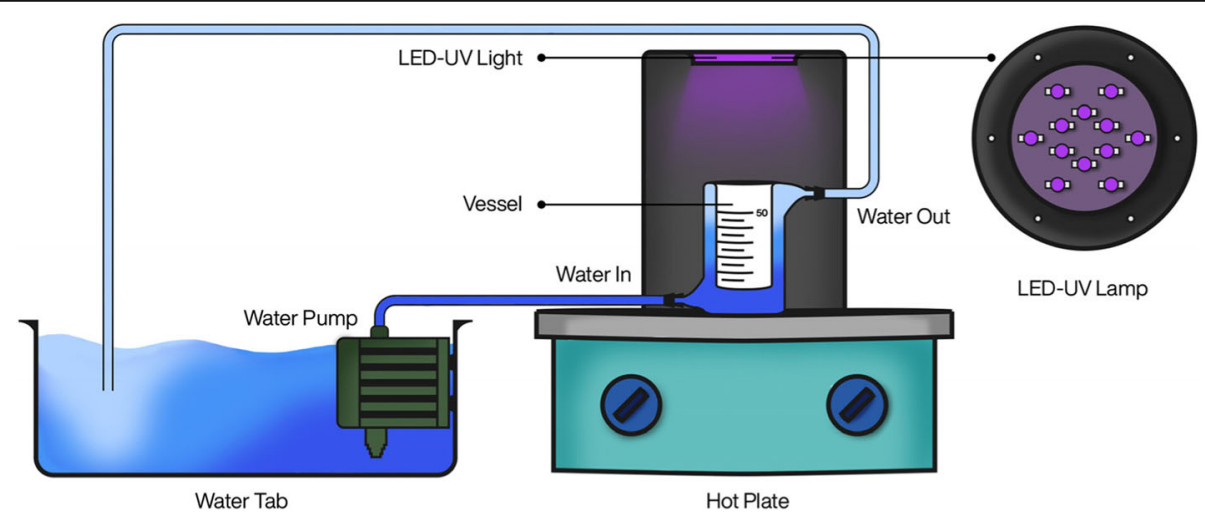

Fig. 1 Design of the photocatalytic reactor 

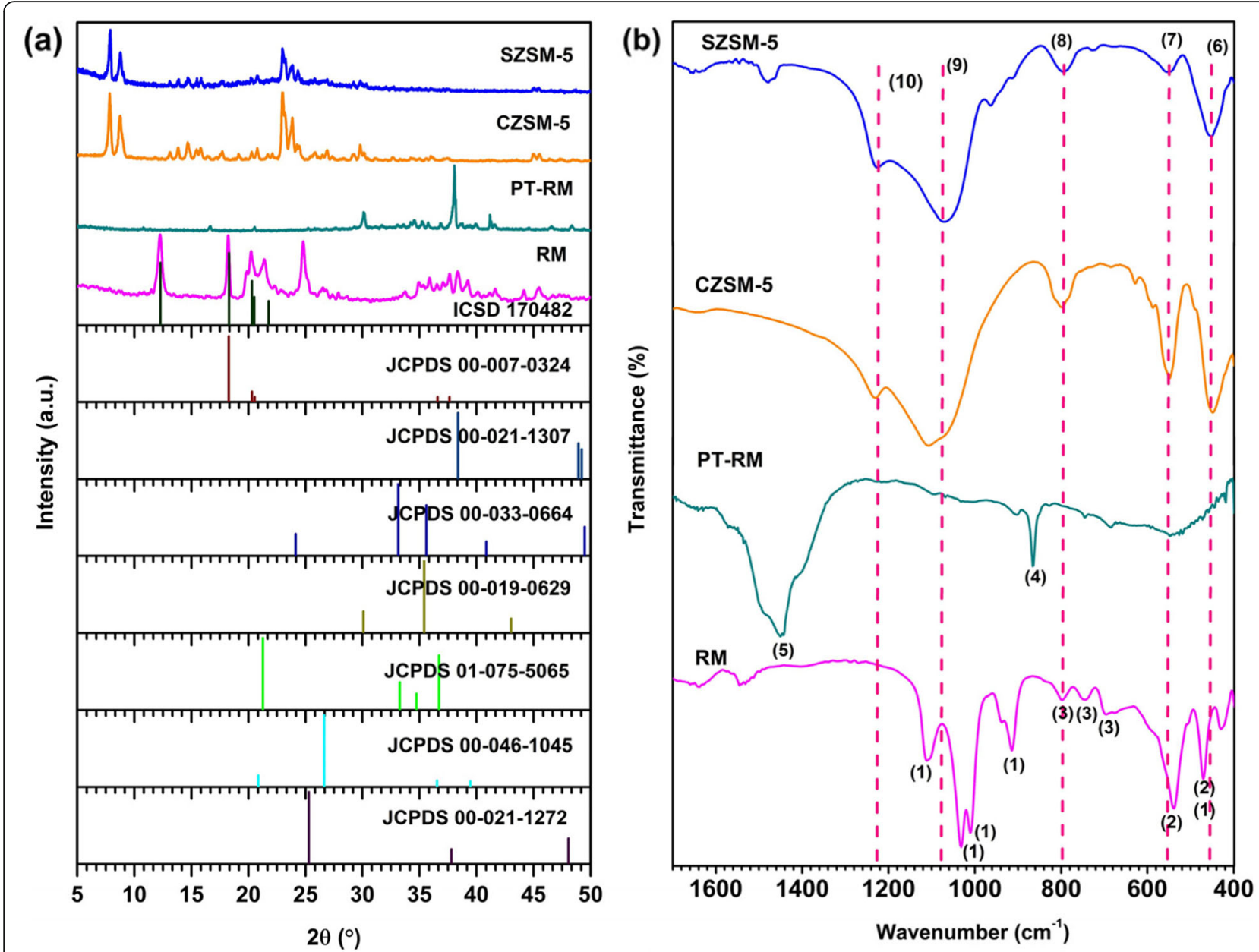

Fig. 2 Confirmation of ZSM-5 formation based on (a) XRD results and (b) FTIR spectra

show a peak at $450 \mathrm{~cm}^{-1}$, which indicates a bending vibration of $\mathrm{Al}-\mathrm{O}-\mathrm{Al}$ or $\mathrm{Si}-\mathrm{O}-\mathrm{Si}$. The presence of $\mathrm{Al}$ $\mathrm{O}-\mathrm{Al}$ and $\mathrm{Si}-\mathrm{O}-\mathrm{Si}$ vibrations is also indicated by the peaks at 798 and $1100 \mathrm{~cm}^{-1}$, which are associated with the external and internal symmetric-asymmetric stretching vibration modes, respectively. These peaks are related to the changes in the tetrahedral structure of ZSM-5 [30]. The details of the FTIR spectra are summarized in Table 1.

An SEM instrument was used to assess the morphology of ZSM-5 and micrographs of the synthesized ZSM-5 are shown in Fig. 3a and b. Figure 3a and b show that ZSM-5 has a cubic microcrystallite morphology. The formation of nonuniform aggregates was also observed due to the short crystallization time leading to incomplete crystallization of amorphous aluminosilicate species [36]. The particle size distribution presented in Fig. 3c shows that the average particle size of the synthesized ZSM-5 was $2.1 \mu \mathrm{m}$.

\subsection{Impregnation of $\mathrm{ZnO}$ onto $\mathrm{ZSM}-5$}

The effects of $\mathrm{ZnO}$ impregnation on the structure, morphology, and optical properties of ZSM-5 were investigated in this study. As shown in the XRD and FTIR spectra in Fig. 4, the loading of ZnO into ZSM-5 did not break the ZSM-5 network. As the percentage of impregnated $\mathrm{ZnO}$ increased, however, the ZSM-5 peaks decreased in intensity due to the predominant $\mathrm{ZnO}$ peaks.

The successful formation of ZnO-impregnated ZSM-5 was confirmed by the appearance of $\mathrm{ZnO}$ wurtzite peaks at $2 \theta=31.76,34.41$, and $36.24^{\circ}$, matching JCPDS data no. 36-1451. The FTIR spectra also confirmed the formation of $\mathrm{ZnO}$ on the surface of ZSM- 5 by the appearance of $\mathrm{Zn}^{2+}-\mathrm{O}^{2-}$ at 520 and $420 \mathrm{~cm}^{-1}$, as shown in Fig. S1 of Supplemental Materials. These facts also signify that $\mathrm{ZnO}$ and $\mathrm{ZSM}-5$ interacted only physically but not chemically.

As shown in Fig. 5a and b, the morphology of 34$\mathrm{ZnO} / \mathrm{ZSM}-5$ has similar cubic microcrystallite features 
Table 1 Summary of the FTIR results

\begin{tabular}{|c|c|c|c|c|}
\hline Sample & $\begin{array}{l}\text { Wavenumber } \\
\left(\mathrm{cm}^{-1}\right)\end{array}$ & Label & Interpretation & Ref \\
\hline \multirow[t]{3}{*}{ RM } & $\begin{array}{l}1112,1030,1008 \\
960,479\end{array}$ & (1) & Si-O bond in Quartz & [30] \\
\hline & 559,479 & (2) & Fe-O bond in Hematite and Magnetite & [31] \\
\hline & $812,740,685$ & (3) & Al-O bonds & [32] \\
\hline \multirow[t]{2}{*}{ PT-RM } & 870 & (4) & Sodium aluminate & [33] \\
\hline & 1420 & (5) & Sodium silicate & \\
\hline \multirow{5}{*}{$\begin{array}{l}\text { SZSM-5 and } \\
\text { CZSM-5 }\end{array}$} & 450 & (6) & Bending vibration of T-O-T ( $\mathrm{T}$ is $\mathrm{Al}$ or $\mathrm{Si}$ atom) & [29] \\
\hline & 540 & (7) & $\begin{array}{l}\text { Asymmetric stretching vibration of the double five-membered ring (D5R) as a characteristic of } \\
\text { pentasil MFI-type zeolite }\end{array}$ & [29] \\
\hline & 798 & (8) & External symmetric-asymmetric stretching mode of T-O-T (between $\mathrm{TO}_{4}$ tetrahedral) & [29] \\
\hline & 1100 & (9) & Internal symmetric-asymmetric stretching mode of T-O-T (between $\mathrm{TO}_{4}$ tetrahedral) & [34] \\
\hline & 1220 & (1) & Asymmetric stretching mode of T-O-T (between $\mathrm{TO}_{4}$ tetrahedral) & [35] \\
\hline
\end{tabular}

similar to those of pure ZSM-5 (Fig. 3). The aggregate particles enveloping the microcrystallite of ZSM-5 indicated that $\mathrm{ZnO}$ was successfully impregnated on the surface of ZSM-5. This result is also supported by the Energy dispersive X-Ray spectroscopy (EDX) results in Figs. 5d-h. According to the EDX result, the $\mathrm{ZnO}$ particles cover the ZSM-5 surface, which is undesirable, because the excessive $\mathrm{ZnO}$ particle covering decreases the surface area and pore volume of ZSM-5 which is verified by the isotherm adsorption results. According to Fig. 6a, as-prepared samples exhibited type IV isotherm, the typical isotherm of mesoporous material. The
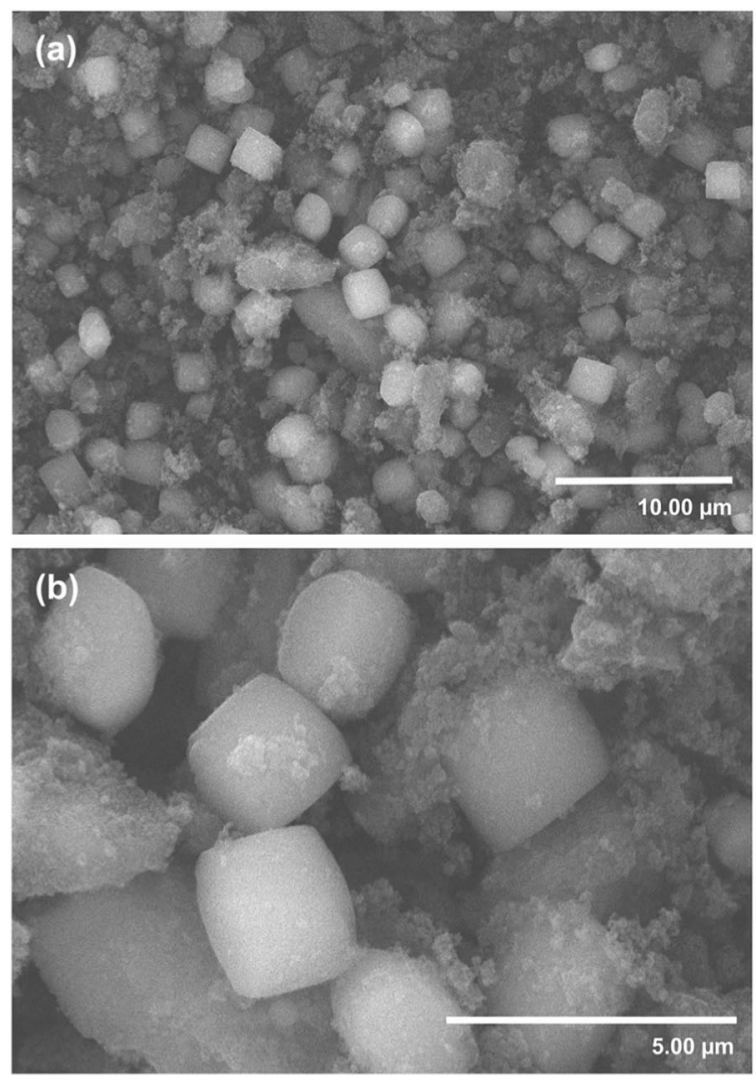

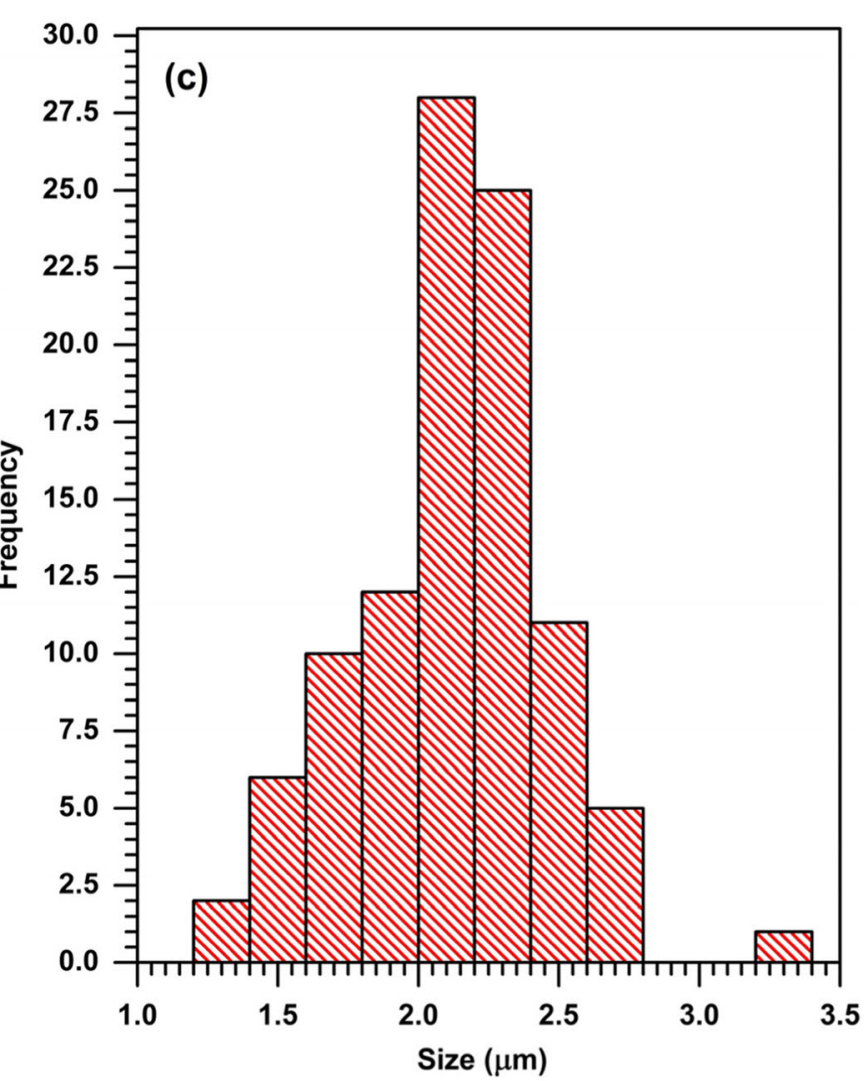

Fig. 3 Micrograph $(\mathbf{a}, \mathbf{b})$ and particle size distribution (c) of ZSM-5 

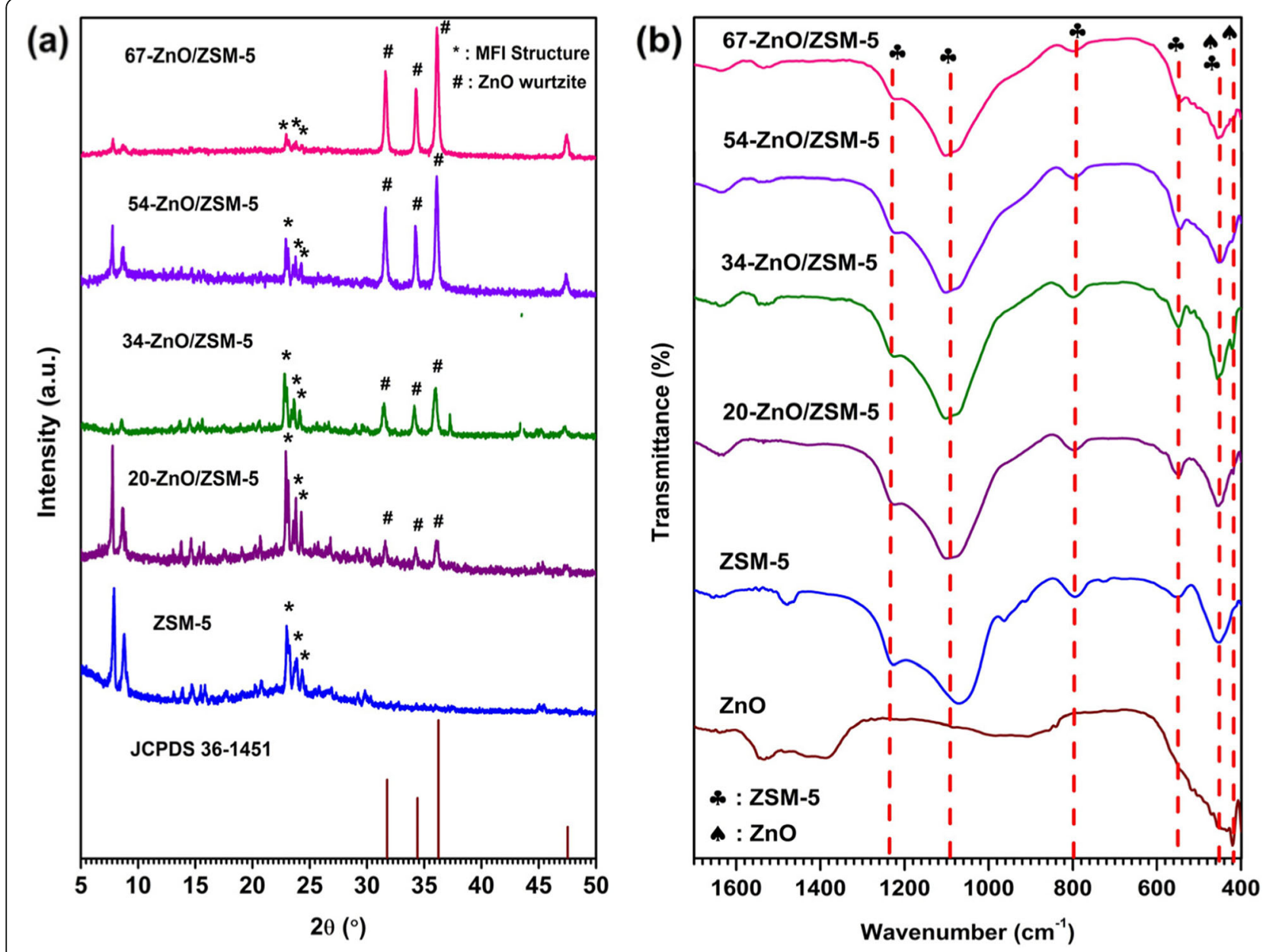

Fig. 4 Influence of ZnO on the (a) XRD pattern and (b) FTIR spectra of ZSM-5

formation of mesoporous was indicated by increase adsorbed $\mathrm{N}_{2}$ at $\mathrm{P} / \mathrm{P}_{0}$ of $0.2-0.52$. The presence of $\mathrm{ZnO}$ on ZSM-5 reduced nitrogen uptake which indicated a decrease in surface area. The presence of $\mathrm{ZnO}$ on ZSM5 also significantly clogged the pore volume of $\mathrm{ZnO} /$ $\mathrm{ZSM}-5$, which indicated the possibility of $\mathrm{ZnO}$ within the mesopores. Based on the Fig. 6a, the increase in pore diameter after impregnation was due to selectively closing the smaller pores by $\mathrm{ZnO}$ loading and leading to the larger as remaining pores for the physisorption process. All parameters of the textural properties of the samples are listed in Table 2.

The UV-Vis absorption spectra and the band gap measurement results in Fig. 7 show that $\mathrm{ZnO}$ loading enhances the absorption in the UV area. This showed that $\mathrm{ZnO}$ loading of $20 \% \mathrm{w} / \mathrm{w}$ onto ZSM-5 induced only a small enhancement in the absorption ability in the UV range, whereas $34 \% \mathrm{w} / \mathrm{w}$ loading and higher resulted in a significant enhancement in the UV absorption ability. Figure $7 \mathrm{~b}$ shows the bandgap measurement results for
34-ZnO/ZSM-5, 54-ZnO/ZSM-5, and 67-ZnO/ZSM-5, which were $3.2,3.18$, and $3.17 \mathrm{eV}$, respectively, whereas the band gap of pure $\mathrm{ZnO}$ is $3.15 \mathrm{eV}$.

\subsection{Photocatalytic activity toward MB degradation}

A preliminary assessment was performed to obtain the optimum percentage of $\mathrm{ZnO}$ loading onto $\mathrm{ZSM}-5$. According to Fig. 8, the $\mathrm{ZnO}$ loading of $34 \% \mathrm{w} / \mathrm{w}$ onto ZSM- 5 shows the best performance in removing $\mathrm{MB}$ dyes among all tested samples. Higher amounts of $\mathrm{ZnO}$ loading led to a decrease in the surface area than ZSM5 . This results in a decrease in the maximum adsorption capacity, and hence decreases MB decolorization. Higher amounts of $\mathrm{ZnO}$ loading also led to photosensitive surface covering, thus hindering or even reflecting light penetration [37]. The subsequent experiment of $\mathrm{MB}$ decolorization by photocatalytic processes was then continued by using $\mathrm{ZnO} / \mathrm{ZSM}-5$ at $34 \% \mathrm{w} / \mathrm{w}$.

The influence of the initial MB concentration on the photocatalytic activities was studied to determine the 

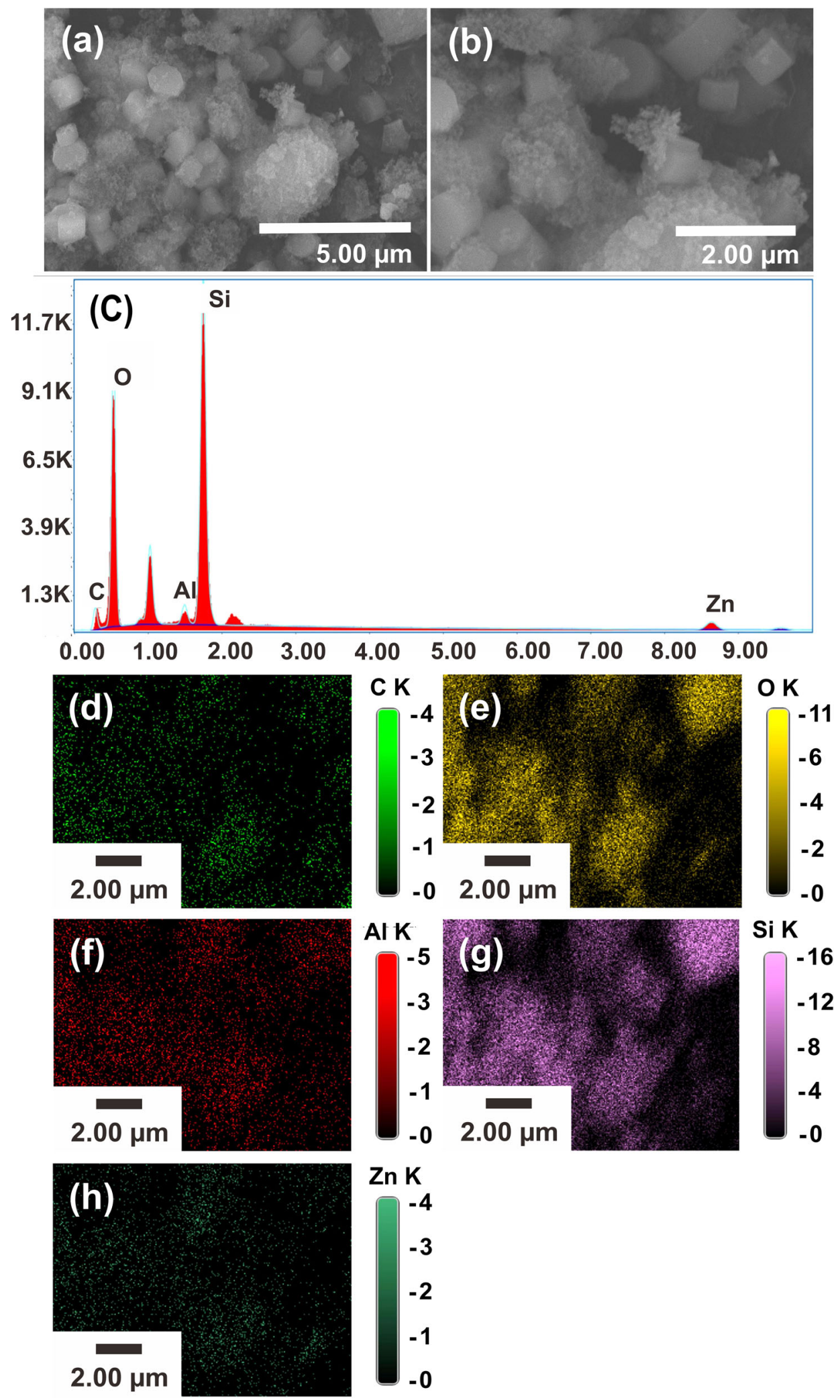

Fig. 5 SEM (a-b), EDX (c) and mapping (d-h) images of 34-ZnO/ZSM-5 


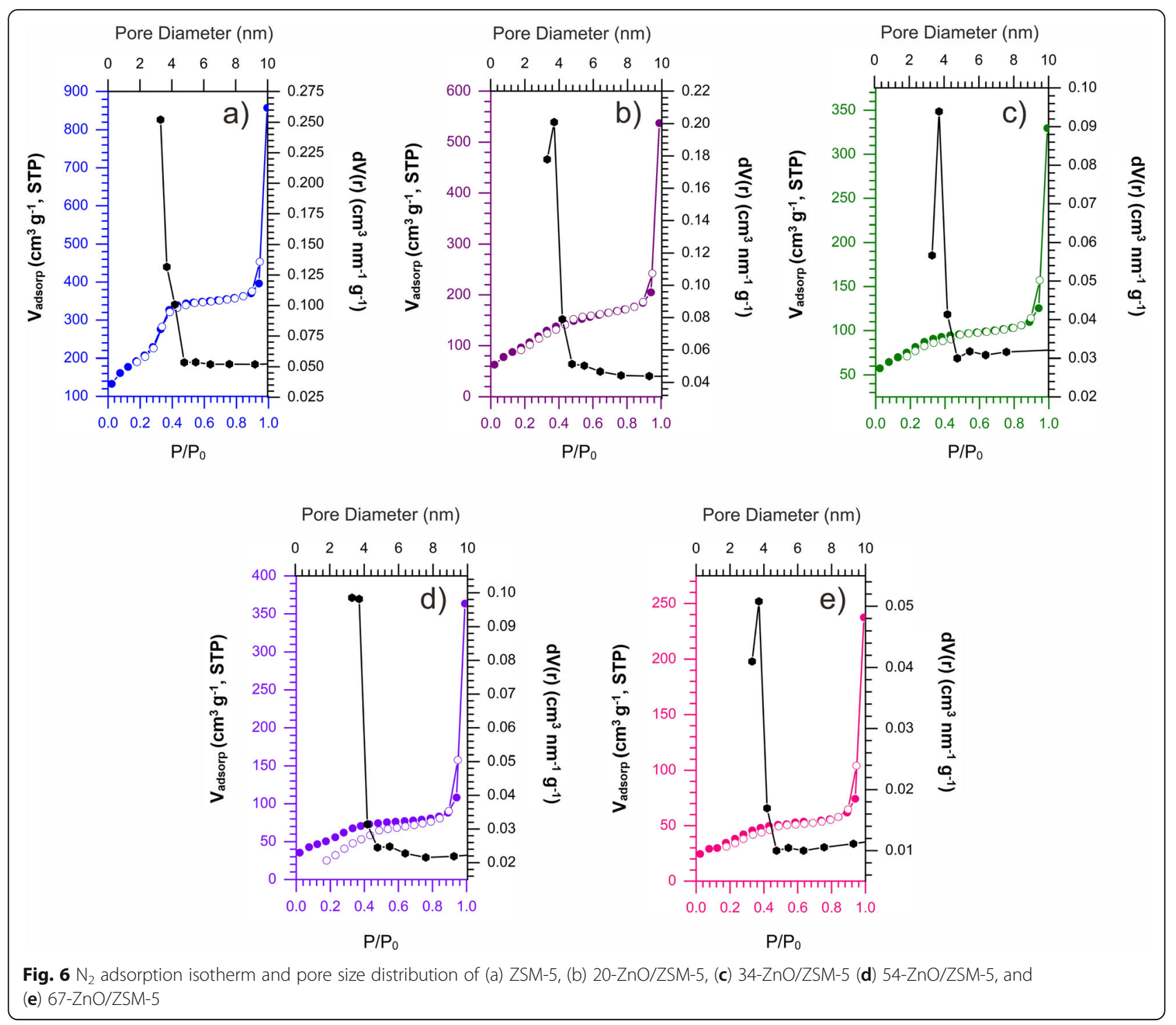

range of $\mathrm{MB}$ concentrations in which the photocatalysts showed adequate activity. The results presented in Fig. 9 show the photocatalytic activities of 34-ZnO/ZSM-5 and ZSM-5. Figure 9a shows that ZSM-5 under irradiation shows a lower $\mathrm{MB}$ decolorization activity than without irradiation. This fact indicates that ZSM-5 did not undergo photocatalytic activity since UV-LED irradiation causes the temperature of the solution to increase, which, in turn, causes a decrease in the adsorption process. Under UV-LED irradiation, 34-ZnO/ZSM-5 exhibited good $\mathrm{MB}$ decolorization activities at all tested MB concentrations compared to those without UV-LED irradiation. This suggests that the presence of $\mathrm{ZnO}$ on the ZSM-5 surface induces photocatalytic activity. As shown in Fig. 9a, the same results were obtained between ZSM-5 and $34-\mathrm{ZnO} / \mathrm{ZSM}-5$ at $80 \mathrm{mg} \mathrm{L}^{-1}$, which demonstrated that ZSM-5 reached the maximum adsorption capacity where it removed $\mathrm{MB}$ from the

Table 2 Textural properties of ZSM-5 and ZnO/ZSM-5

\begin{tabular}{llllll}
\hline Parameters & ZSM-5 & $\mathbf{2 0 - Z n O / Z S M - 5 ~}$ & $\mathbf{3 4 - Z n O / Z S M - 5}$ & $\mathbf{5 4 - Z n O / Z S M - 5}$ & $\mathbf{6 7 - Z n O / Z S M - 5}$ \\
\hline $\mathrm{S}_{\text {BET }}\left(\mathrm{m}^{2} \mathrm{~g}^{-1}\right)$ & 735 & 390 & 278 & 200 & 137 \\
$V_{\text {total }}\left(\mathrm{cm}^{3} \mathrm{~g}^{-1}\right)$ & 0.61 & 0.32 & 0.20 & 0.17 & 0.12 \\
D $_{\text {meso }}(\mathrm{nm})$ & 3.29 & 3.71 & 3.71 & 3.29 & 3.71 \\
\hline
\end{tabular}



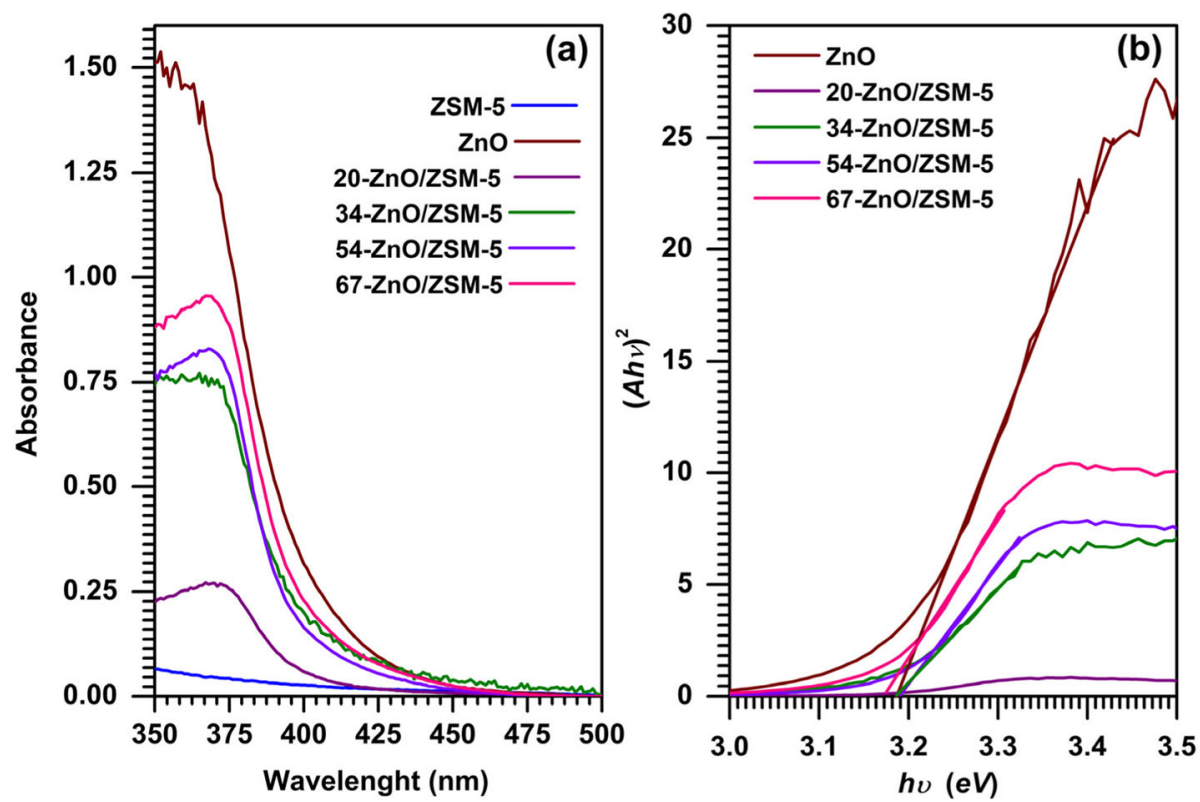

Fig. 7 (a) Absorption spectra and (b) band gap calculation of ZnO, 34-ZnO/ZSM-5, 54-ZnO/ZSM-5, 67-ZnO/ZSM-5, and ZSM-5

solution without the photocatalytic process. At MB concentrations greater than $80 \mathrm{mg} \mathrm{L}^{-1}$, the photocatalytic process can be used to assist the adsorption process in removing $\mathrm{MB}$ dye.

To monitor the degradation process, LC-MS analysis was carried out after the photocatalytic process. Figure 10 displays the LC spectra of MB after the photocatalytic process. The mass spectra are shown in Figs. S2-S7. The
LC-MS results show that the first step of MB degradation is ring opening through the cleavage of the $\mathrm{C}-\mathrm{N}=\mathrm{C}$ bond [38]. Based on the formed compounds, the proposed mechanism by Jia et al. is more suitable for the next degradation process in this study [39]. It was also observed that the $\mathrm{m} / \mathrm{z}$ of 270 in the mass spectra indicated the formation of azure B during the degradation process.

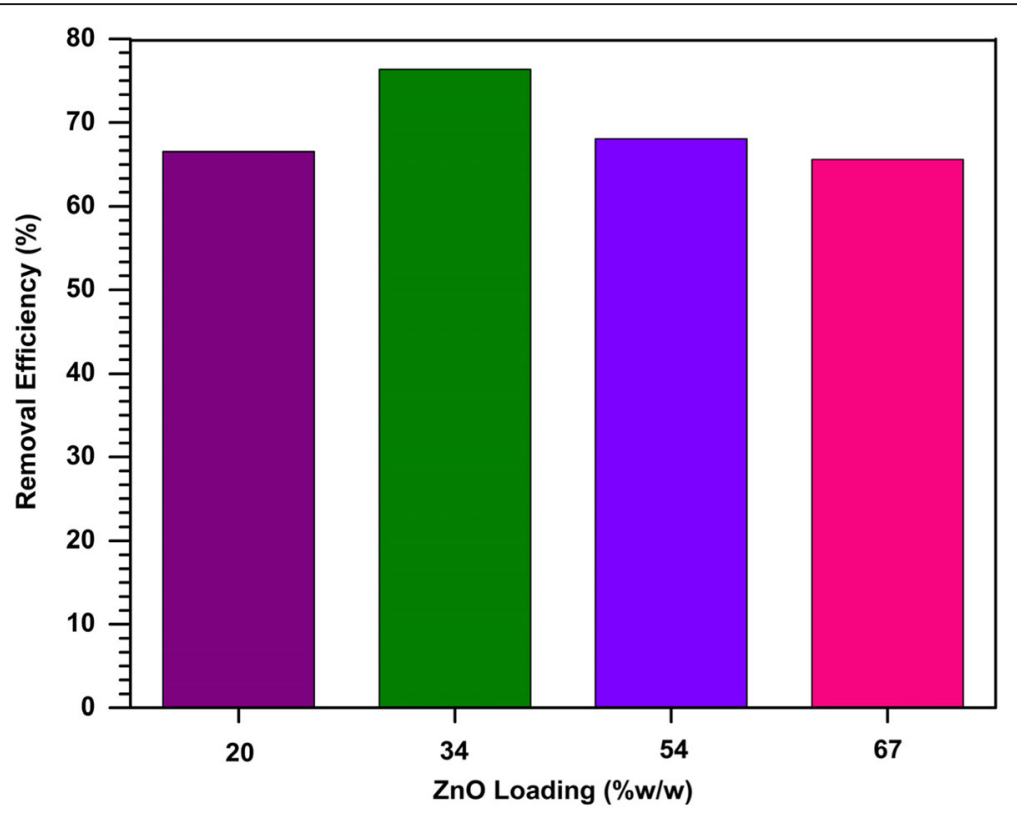

Fig. 8 Preliminary study of the effect of $\mathrm{ZnO}$ loading on $Z S M-5\left(C_{M B}=100 \mathrm{mg} \mathrm{L}^{-1}, \mathrm{pH}=7, t=60 \mathrm{~min}\right)$ 

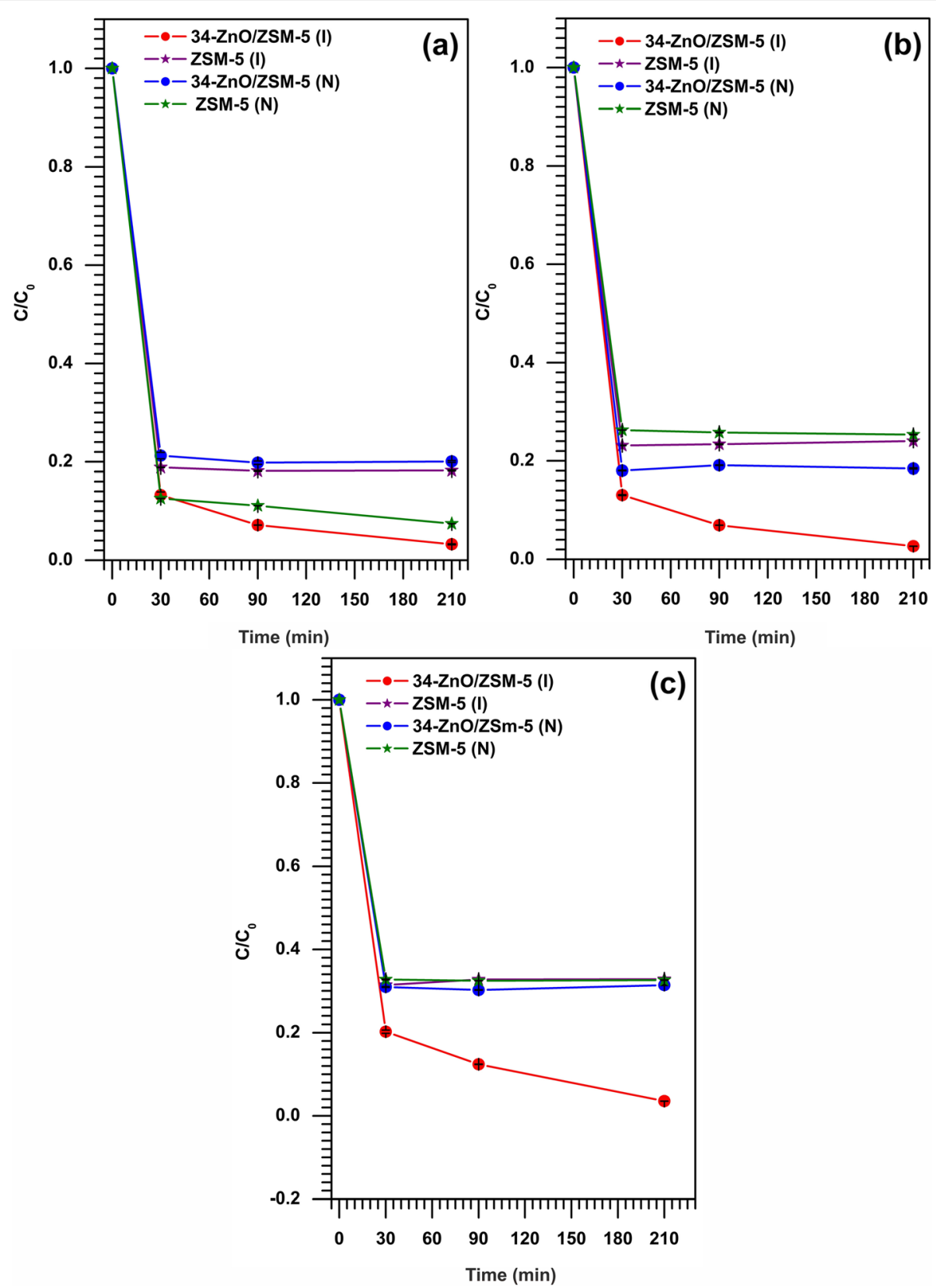

Fig. 9 Influence of the initial MB concentration at (a) $80 \mathrm{mg} \mathrm{L}^{-1}$, (b) $90 \mathrm{mg} \mathrm{L}^{-1}$ and (c) $100 \mathrm{mg} \mathrm{L}^{-1}$ with UV-LED irradiation (I) and without irradiation $(\mathrm{N})$

\section{Conclusions}

The impregnation of $\mathrm{ZnO}$ on ZSM-5 was successfully synthesized by wet impregnation method. The presence of $\mathrm{ZnO}$ on ZSM-5 did not break the ZSM-5 network and interacted only physically, led to decrease in the surface area. The presence of $\mathrm{ZnO}$ significantly enhanced the decolorization of $\mathrm{MB}$ by adsorption and photocatalytic process. $34 \% \mathrm{w} / \mathrm{w}$ loading of $\mathrm{ZnO}$ showed the optimum decolorization of
MB was due to increase in the photosensitive sites of sample which associated with a high adsorption process. The effect of initial concentration of $\mathrm{MB}$ showed the photocatalytic process can be used to assist the adsorption process in removing $\mathrm{MB}$ dye at $\mathrm{MB}$ concentrations greater than $80 \mathrm{mg} \mathrm{L}^{-1}$. The photocatalytic mechanism of $\mathrm{ZnO} / \mathrm{ZSM}-5$ occurred by the formation of azure $\mathrm{B}$ which indicated ring opening through cleavage of the $\mathrm{C}-\mathrm{N}=\mathrm{C}$ bond. 


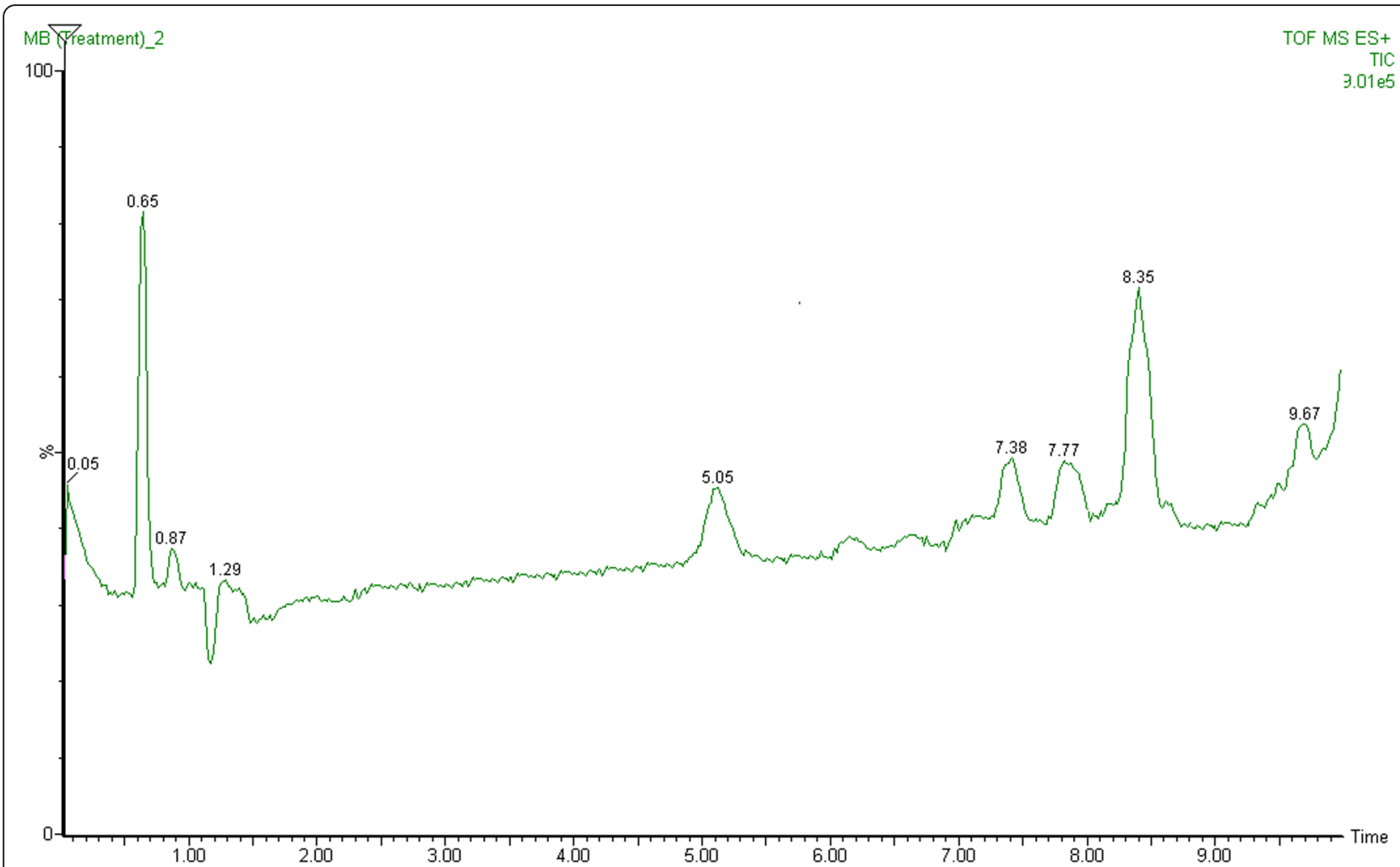

Fig. $10 L C$ spectra of the MB solution after the photocatalytic process

\section{Supplementary Information}

The online version contains supplementary material available at https://doi. org/10.1186/s42834-021-00113-8.

Additional file 1. Supplementary materials. Fig. S1 The FTIR spectra of a) $\mathrm{ZnO}$, b) ZSM-5, c) 20-ZnO/ZSM-5, d) 34-ZnO/ZSM-5, e) 54-ZnO/ZSM5 and $67-\mathrm{ZnO} / \mathrm{ZSM}-5$ in the wavenumber range of $600-400 \mathrm{~cm}^{-1}$. The red dash line is ZSM-5 and the blue dash line is ZnO.Fig. S2 The mass spectra of MB after degradation process at retention time of 0.65 . Fig. S3 The mass spectra of MB after degradation process at retention time of 0.87 . Fig. S4 The mass spectra of $M B$ after degradation process at retention time of 5.05 Fig. S5 The mass spectra of MB after degradation process at retention time of 7.38. Fig. S6 The mass spectra of MB after degradation process at retention time of 7.70. Fig. S7 The mass spectra of MB after degradation process at retention time of 8.35

\section{Acknowledgements}

The Deputy for Research and Development, Ministry of Research and Technology of Republic Indonesia is acknowledged for supporting the financial research through the PDUPT Scheme with contract number 1200/ PKS/ITS/2020.

\section{Authors' contributions}

This research is a part of the TH dissertation. RS aided some experimental works and manuscript preparation. DP and YK are the promotor and copromotor of TH who supervised the work and manuscript writing. All authors read and approved the final manuscript.

\section{Funding}

This research was supported by grants from the Deputy for Research and Development, Ministry of Research and Technology of Republic Indonesia through the PDUPT Scheme with contract number 1200/PKS/ITS/2020.

\section{Availability of data and materials}

The datasets analyzed during this case report are available from the corresponding author on reasonable request.

\section{Declarations}

\section{Competing interests}

The authors declare they have no competing interests.

Received: 9 February 2021 Accepted: 2 December 2021

Published online: 10 January 2022

\section{References}

1. Mukiza E, Zhang LL, Liu XM, Zhang N. Utilization of red mud in road base and subgrade materials: a review. Resour Conserv Recy. 2019;141:187-99.

2. Gore MS. Geotechnical characterization of bauxite residue (red mud) [Ph.D. Dissertation]. Austin: Univ of Texas; 2015.

3. Rai S, Wasewar KL, Mukhopadhyay J, Yoo CK, Uslu H. Neutralization and utilization of red mud for its better waste management. Arch Environ Sci. 2012;6:13-33.

4. Sahu RC, Patel R, Ray BC. Adsorption of Zn (II) on activated red mud: neutralized by $\mathrm{CO}_{2}$. Desalination. 2011;266:93-7.

5. Klauber C, Grafe M, Power G. Bauxite residue issues: II. Options for residue utilization. Hydrometallurgy. 2011;108:11-32. 
6. Orescanin V, Nad K, Mikelic L, Mikulic N, Lulic S. Utilization of bauxite slag for the purification of industrial wastewaters. Process Saf Environ. 2006;84: 265-9.

7. Dotto J, Fagundes-Klen MR, Veit MT, Palacio SM, Bergamasco R. Performance of different coagulants in the coagulation/flocculation process of textile wastewater. J Clean Prod. 2019;208:656-65.

8. Gao JY, Gao FZ, Zhu F, Luo XH, Jiang J, Feng L. Synergistic coagulation of bauxite residue-based polyaluminum ferric chloride for dyeing wastewater treatment. J Cent South Univ. 2019;26:449-57.

9. Pradhan J, Das J, Das S, Thakur RS. Adsorption of phosphate from aqueous solution using activated red mud. J Colloid Interf Sci. 1998;204:169-72.

10. Lopez E, Soto B, Arias M, Nunez A, Rubinos D, Barral MT. Adsorbent properties of red mud and its use for wastewater treatment. Water Res. 1998;32:1314-22.

11. Eamsiri A, Jackson WR, Pratt KC, Christov V, Marshall M. Activated red mud as a catalyst for the hydrogenation of coals and of aromatic compounds. Fuel. 1992;71:449-53.

12. Pratt KC, Christoverson V. Hydrogenation of a model hydrogen-donor system using activated red mud catalyst. Fuel. 1982:61:460-2

13. Ordonez S, Sastre H, Diez FV. Catalytic hydrodechlorination of tetrachloroethylene over red mud. J Hazard Mater. 2001;81:103-14.

14. Sushil S, Batra VS. Catalytic applications of red mud, an aluminium industry waste: a review. Appl Catal B-Environ. 2008:81:64-77.

15. Rubinos DA, Barral MT. Fractionation and mobility of metals in bauxite red mud. Environ Sci Pollut R. 2013;20:7787-802

16. Brunori C, Cremisini C, Massanisso P, Pinto V, Torricelli L. Reuse of a treated red mud bauxite waste: studies on environmental compatibility. J Hazard Mater. 2005;117:55-63.

17. Hua YM, Heal KV, Friesl-Hanl W. The use of red mud as an immobiliser for metal/metalloid-contaminated soil: a review. J Hazard Mater. 2017; 325:17-30.

18. Das B, Mohanty K. A review on advances in sustainable energy production through various catalytic processes by using catalysts derived from waste red mud. Renew Energ. 2019;143:1791-811.

19. de Lima Procopio RE, da Silva IR, Martins MK, de Azevedo JL, de Araujo JM Antibiotics produced by Streptomyces. Braz J Infect Dis. 2012;16:466-71.

20. Abdolali A, Guo WS, Ngo HH, Chen SS, Nguyen NC, Tung KL. Typical lignocellulosic wastes and by-products for biosorption process in water and wastewater treatment: a critical review. Bioresour Technol. 2014;160:57-66.

21. Boukhemkhem A, Rida K. Improvement adsorption capacity of methylene blue onto modified Tamazert kaolin. Adsorpt Sci Technol. 2017;35:753-73.

22. Zouzelka R, Kusumawati Y, Remzova M, Rathousky J, Pauporte T. Photocatalytic activity of porous multiwalled carbon nanotube- $\mathrm{TiO}_{2}$ composite layers for pollutant degradation. J Hazard Mater. 2016:317:52-9.

23. Subagyo R, Kusumawati Y, Widayatno WB. Kinetic study of methylene blue photocatalytic decolorization using zinc oxide under UV-LED irradiation. AIP Conf Proc. 2020:2237:020001.

24. Shams-Ghahfarokhi Z, Nezamzadeh-Ejhieh A. As-synthesized ZSM-5 zeolite as a suitable support for increasing the photoactivity of semiconductors in a typical photodegradation process. Mat Sci Semicon Proc. 2015;39:265-75.

25. Tehubijuluw $H$, Subagyo R, Yulita MF, Nugraha RE, Kusumawati Y, Bahruji $H$, et al. Utilization of red mud waste into mesoporous ZSM-5 for methylene blue adsorption-desorption studies. Environ Sci Pollut R. 2021;28:37354-70.

26. Prasetyoko D, Rustam R, Ediati R, Septiyana B, Zein YM, Bahruji H, et al. Direct synthesis of ZSM-5 from kaolin and the influence of organic template. Malays J Fundam Appl. 2017;13:137-42.

27. Sacco O, Vaiano V, Matarangolo M. ZnO supported on zeolite pellets as efficient catalytic system for the removal of caffeine by adsorption and photocatalysis. Sep Purif Technol. 2018;193:303-10.

28. Hu T, Gao WY, Liu X, Zhang YF, Meng CG. Synthesis of zeolites Na-A and $\mathrm{Na}-\mathrm{X}$ from tablet compressed and calcinated coal fly ash. Roy Soc Open Sci. 2017:4:170921.

29. Pan F, Lu XC, Wang Y, Chen SW, Wang TZ, Yan Y. Synthesis and crystallization kinetics of ZSM-5 without organic template from coal-series kaolinite. Micropor Mesopor Mat. 2014;184:134-40.

30. Yue YY, Kang Y, Bai Y, Gu LL, Liu HY, Bao J, et al. Seed-assisted, templatefree synthesis of ZSM-5 zeolite from natural aluminosilicate minerals. Appl Clay Sci. 2018;158:177-85.

31. Singh S, Aswath MU, Das Biswas R, Ranganath RV, Choudhary HK, Kumar R, et al. Role of iron in the enhanced reactivity of pulverized red mud: analysis by Mössbauer spectroscopy and FTIR spectroscopy. Case Stud Constr Mat. 2019;11:e00266.

32. Wang YS, Muramatsu A, Sugimoto T. FTIR analysis of well-defined a- $\mathrm{Fe}_{2} \mathrm{O}_{3}$ particles. Colloid Surface A. 1998;134:281-97.

33. Dodoo-Arhin D, Konadu DS, Annan E, Buabeng FP, Yaya A, AgyeiTuffour B. Fabrication and characterisation of Ghanaian bauxite red mud-clay composite bricks for construction applications. Am J Mater Sci. 2013;3:110-9.

34. Ma SH, Zheng SL, Xu HB, Zhang Y. Spectra of sodium aluminate solutions. T Nonferr Metal Soc. 2007;17:853-7.

35. Nezamzadeh-Ejhieh A, Shams-Ghahfarokhi Z. Photodegradation of methyl green by nickel-dimethylglyoxime/ZSM-5 zeolite as a heterogeneous catalyst. J Chem-NY. 2013;2013:104093.

36. Ye N, Chen Y, Yang JK, Liang S, Hu Y, Hu JP, et al. Transformations of Na, Al, $\mathrm{Si}$ and Fe species in red mud during synthesis of one-part geopolymers. Cement Concrete Res. 2017;101:123-30.

37. Achilleos A, Hapeshi E, Xekoukoulotakis NP, Mantzavinos D, Fatta-Kassinos D. Factors affecting diclofenac decomposition in water by UV-A/TiO photocatalysis. Chem Eng J. 2010;161:53-9.

38. Mustapha FH, Jalil AA, Mohamed M, Triwahyono S, Hassan NS, Khusnun NF et al. New insight into self-modified surfaces with defect-rich rutile $\mathrm{TiO}_{2}$ as a visible-light-driven photocatalyst. J Clean Prod. 2017:168:1150-62.

39. Jia PQ, Tan HW, Liu KR, Gao W. Synthesis, characterization and photocatalytic property of novel ZnO/bone char composite. Mater Res Bull. 2018;102:45-50

\section{Publisher's Note}

Springer Nature remains neutral with regard to jurisdictional claims in published maps and institutional affiliations.
Ready to submit your research? Choose BMC and benefit from:

- fast, convenient online submission

- thorough peer review by experienced researchers in your field

- rapid publication on acceptance

- support for research data, including large and complex data types

- gold Open Access which fosters wider collaboration and increased citations

- maximum visibility for your research: over $100 \mathrm{M}$ website views per year

At BMC, research is always in progress.

Learn more biomedcentral.com/submissions 